\title{
Financial Risk of Indebted Companies: A Study of the Impact of Financial Structure and the Earnings Growth
}

\author{
Tahiri Amira \\ Hassan II University \\ Yerrou Hafssa \\ Hassan II University
}

The choice of a financial structure by the companies is a strategic decision which frames their use of the fund resources. The companies that are financially well-off resort directly to the equity capital by opting for a perfect autonomy. It also turns out that this is an obvious option, rather than using external resources which come along with financial expenses.

In this article, we are interested in indebted companies and their growth and the impact of the latter on the Beta of their representative stocks. In order to answer this problem, an empirical study was conducted on a panel of 44 Moroccan companies listed on the Casablanca Stock Exchange between 2008 and 2019. Based on the results obtained, we have shown that the level of indebtedness and earnings growth do not have a significant influence on the financial risk measured by the Beta of the companies studied. In this case, we come back to a neutrality of the financial structure and the earnings growth on the Beta displayed by these companies.

Keywords: debt, financial structure, financial risk, cost of capital, earnings growth

\section{INTRODUCTION}

In an environment where any financial resource is important for financing the creation of wealth and hence the increase in the value of the company, debt is imposed on companies (Molay, 2010), whose ability to self-finance its commitments or new investments, remains insufficient. The coverage of needs by medium- and long-term debt for certain companies, whatever the nature of this debt, will put the company in situations of insolvency in relation to bondholders and consequently may cause its value to vary according to the level of debt chosen, or even according to its exposure to the risk of bankruptcy.

For the company, debt is a resource that allows it to adjust its current and future needs in the event of inability to cover the desired financing or future investments (Beattie, et al., 2006). Thus, the financial structure of a company with debt influences its value within the framework of imperfect financial markets, which leads us to focus on this structure, especially for firms whose debt is important to cover their need for funds (Aivazian, et al., 2005), and to verify whether the option of taking on debt at a given level will enable the firm to increase or decrease its value. 
Resorting to debt is a multifaceted signal (Ross, 1977), it is the result of an expression of need for financing in the face of growth opportunities (Ding, et al., 2020), but it can also be understood by others as a sign of financial difficulties. Signaling can also extend to the growth of the company's earnings. At stronger rates, the company's ßeta is positively affected (Vernimmen; Letter No. 23).

Financial theory as a set of theoretical approaches, develops a whole range of tools for financial decision making. It makes it possible to understand the impact of these decisions on the variation in value (Modigliani \& Miller, 1958), in the presence, of course, of the idea of optimizing the resources involved (Leland, 1994). Portfolio theory was charting a new course for finance (Fama \& French, 2005), notably with the work of William F. Sharpe in 1964 and the modern portfolio management that relate each individual asset to the risk of all the assets in the market, thus revitalizing the CAPM.

Through this article, we seek to study the impact of financial structure and earnings growth on the financial risk of indebted companies.

Debt financing generates additional financial risk, which is identified as a component of the company's overall risk and is measured by its $\beta$ eta.

Based on our problem statement, there are a number of important questions that intrigue us. If the source of debt financing influences the company's value, what then will be the financial risk of the company's stock? Does a leveraged/indebted ßeta not move in parallel with the company's gearing? If as a first step a deleveraged ßeta refers to the risk of the share in the absence of debt, would we have a collinearity of this leveraged value with respect to the company's financial structure?

Apart from economic risks, financial risks may relate to variations in flows that directly affect the financial sphere. The growth in earnings presents a quality of information relative to the flows of results that the company generates. Will the magnitude of their growth rate be positively or negatively correlated with the company's $\beta$ eta?

Based on the research problem statement, already spelt out, we were able to come up with two research hypotheses $\boldsymbol{H}_{\mathbf{1}}$ and $\boldsymbol{H}_{\mathbf{2}}$ for which:

$\boldsymbol{H}_{\mathbf{1}}$ : The more indebted the company is, the greater would be the increase in its financial costs, thus positively affecting the company's ßeta.

$\boldsymbol{H}_{2}$ : The higher the earnings growth rate, the higher would be the company's Beta. As a result, the greater the flows, the greater the value of the company and subsequently it would be sensitive to any market changes.

The $\beta$ eta variable is considered as a dependent variable, which we will need to explain by the choice of the financial structure $\left(\boldsymbol{H}_{\mathbf{1}}\right)$, and at the same time to explore whether or not it depends on the valuation of net results $\left(\boldsymbol{H}_{2}\right)$.

Thus, in order to answer these different questions and hypotheses, we will first present the variables of the study, their identifications, measurements, and codifications, and then we will turn to the empirical study, discussion and analysis of the results obtained.

\section{THE STUDY VARIABLES: IDENTIFICATIONS, MEASUREMENTS, AND CODIFICATIONS}

In our analysis, two explanatory variables will be studied, namely: The measure of the level of indebtedness that will be quantified by the gearing of the company, and the growth rate of the earnings. The dependent variable representing the financial risk will be qualified by the company's leveraged $\beta$ eta.

\section{The Measurement of Beta as an Additional Financial Risk}

The $\beta$ eta coefficient measures the volatility of the profitability of a stock or a stock portfolio relative to the market. According to the market model: The profitability of a stock/security $(\boldsymbol{i})$ at time $(\boldsymbol{t})$ is given by:

$$
r_{i, t}=\propto_{i}+\beta_{i} r_{m t}+\varepsilon_{i, t}
$$


where:

$$
\begin{array}{ll}
\boldsymbol{r}_{\boldsymbol{i}, \boldsymbol{t}} & : \text { is the profitability of a stock } \mathrm{i} \text { in } \mathrm{t} . \\
\boldsymbol{r}_{\boldsymbol{m} t} & : \text { is the profitability of the market in } \mathrm{t} . \\
\boldsymbol{\varepsilon}_{\boldsymbol{i}, \boldsymbol{t}} & : \text { is the error term specific to stock i in } \mathrm{t} . \\
\propto_{\boldsymbol{i}} & : \text { is a constant. }
\end{array}
$$

The Beta is obtained by calculating the covariance of the profitability of the stock $(\boldsymbol{i})$ with respect to that of the market $(\boldsymbol{m})$, divided by the standard deviation of the market's profitability over a well-defined reference period:

$$
\beta_{i}=\frac{\operatorname{cov}\left(r_{i} ; r_{m}\right)}{\sigma_{r m}}
$$

The beta estimated according to the CAPM model, allows us to have a sensitivity of the stock to a financial structure including a debt, called a leveraged $\beta$ eta. In the absence of debt or by deleveraging the beta, the value obtained is called deleveraged beta.

In this case, and in a universe with taxation, the relationship between $\boldsymbol{\beta}_{\text {leveraged }}$ and $\boldsymbol{\beta}_{\text {unleveraged }}$ is expressed as follows (Franck Bancel, et al., 2014):

$$
\boldsymbol{\beta}_{\text {unleveraged }}=\frac{\boldsymbol{\beta}_{\text {leveraged }}}{1+\left[\left(1-t_{i s}\right) \frac{\boldsymbol{V}_{\boldsymbol{d}}}{\boldsymbol{V}_{\boldsymbol{c} \boldsymbol{p}}}\right]}
$$

with:

$\boldsymbol{t}_{\boldsymbol{i s}}$ : IS rate $; \boldsymbol{V}_{\boldsymbol{d}}$ : Net value of debts ; $\boldsymbol{V}_{\boldsymbol{c} \boldsymbol{p}}$ : Equity value.

Our analytical direction is towards the possibility of finding collinearity between the $\boldsymbol{\beta}_{\text {leveraged }}$ of firms and their gearing. If the financial risk component exists, leverage exerts a risk effect, which is materialized by the difference between the $\boldsymbol{\beta}_{\text {leveraged }}$ and the $\boldsymbol{\beta}_{\text {unleveraged }}$.

As far as we are concerned, and in relation to the use of $\beta$ eta in financial practice, we have opted for a 5 -year $\beta$ eta to be compared in the relationship we are studying, with the gearing and then with the growth rate of the net income of the companies studied.

\section{Gearing}

The "gearing" variable allows us to directly assess the companies' ßêta. In our study, it will be calculated as follows:

$$
\text { Gearing }^{2}=\frac{\text { Net M and LT debt }}{\text { Equity }}
$$

We can also use the debt ratio wherein $R=\frac{\text { Net financial debt }}{C P+\text { net financial debt }}$, whose variation is also related to the gearing. Our choice is based on the direct calculation of the $\beta$ eta, regrouping the gearing, which will allow the direct verification of this correlation.

Regarding financial debts, we considered those of the medium and long term, excluding net cash, to assess the fair value of the debt.

\section{Changes in Net Income/Earning}

In the case of flow-based valuations, the choice between income flows and cash flows remains very delicate. In this our study, and in the light of the financial literature that guides this choice, the growth rate of earnings remains a variable retained by financial analysis and company valuation organizations. 
In this regard, and in relation to the financial literature, we would like to still point out that indebted companies show a $\beta$ eta that has a positive correlation with their gearing. At the same time, for valuation methods based on flows (income flows or cash flows), the higher the income growth rate, the higher the ßeta.

\section{Coding of the Variables in the Study}

The following table groups the main variables that will guide the tests related to our empirical study:

TABLE 1

CODING OF THE STUDY VARIABLES

\begin{tabular}{|c|c|l|c|}
\hline Variables & Estimation method & Nature of the variable & Assigned code \\
\hline Beta & $\frac{\operatorname{Cov}\left(r_{i} ; r_{m}\right)}{\sigma_{r m}}$ & Explained variable & $\boldsymbol{y}_{\mathbf{1}}$ \\
\hline Gearing & $\frac{N e t M \text { and } L T \text { debt }}{E q u i t y}$ & Explanatory variable & $\boldsymbol{x}_{\mathbf{1}}$ \\
\hline $\begin{array}{c}\text { Change in net } \\
\text { income }\end{array}$ & $\left(\frac{R_{2}-R_{1}}{R_{1}}\right) \times 100$ & Explanatory variable & $\boldsymbol{x}_{\mathbf{2}}$ \\
\hline
\end{tabular}

Source: Compiled by authors.

Thereafter we proceed to a successive confrontation between the variable $\boldsymbol{y}_{\mathbf{1}}$, and $\boldsymbol{x}_{\mathbf{1}}$ and $\boldsymbol{x}_{\mathbf{2}}$ respectively to specify the nature of the relationship between the various variables.

\section{THE EMPIRICAL STUDY}

After identifying the nature of the panel used, we will then present the results and discussions relating to the econometric study.

\section{The Study Sample}

In our study, we used accounting data from companies listed on the Casablanca Stock Exchange (Morocco), which until January 31, 2020, constitute 74 companies spread over 25 different business sectors (see Appendix 1).

For special cases (banks and insurance companies), merger or eradication from the stock exchange, or insufficient summary statements for the chosen study horizon, we have retained 44 companies that will constitute our sample over a period from 2008 to 2019, and which are as follows:

\section{TABLE 2}

THE SHARE OF INDEBTED AND NON-INDEBTED COMPANIES IN THE SAMPLE

\begin{tabular}{|l|c|c|c|}
\cline { 2 - 4 } \multicolumn{1}{c|}{} & $\begin{array}{c}\text { Total companies } \\
\text { in the sample }\end{array}$ & Non-indebted companies & Indebted companies \\
\hline Number of companies & 44 & 6 & 38 \\
\hline $\begin{array}{l}\text { Number of observations } \\
\text { (over 12 years) }\end{array}$ & 528 & 72 & 456 \\
\hline Percentages by sub-sample & $\mathbf{1 0 0 \%}$ & $\mathbf{1 4 \%}$ & $\mathbf{8 6 \%}$ \\
\hline
\end{tabular}

Source: Compiled by authors. 
In the majority, $86 \%$ of the companies in our sample resort to debt at different levels to cover their capital needs and face am indebted structure.

TABLE 3

THE SHARE OF COMPANIES WITH MORE THAN 50\% IN DEBTS

\begin{tabular}{|l|c|c|c|}
\cline { 2 - 4 } \multicolumn{1}{c|}{} & $\begin{array}{c}\text { Total indebted enterprises } \\
\text { in the sample }\end{array}$ & $\begin{array}{c}\text { Companies with more } \\
\text { than 50\% debt(*) }\end{array}$ & $\begin{array}{c}\text { Companies with } \\
\text { less than 50\% debt }\end{array}$ \\
\hline Number of companies & 38 & 3 & 35 \\
\hline $\begin{array}{l}\text { Percentages by } \\
\text { category }\end{array}$ & $100 \%$ & $8 \%$ & $92 \%$ \\
\hline
\end{tabular}

Source: Compiled by authors.

${ }^{(*)}$ In relation to the financial structure (debts + Equity).

It should also be noted that among the indebted companies, we find $8 \%$ of companies that do not have financial autonomy (Debt/Debt+Equity $\geq 50 \%$ ). This means that, even in the presence of debt, the companies in the sample rely more on equity while remaining closer to financial autonomy.

\section{Presentation and Discussion of Econometric Results}

The econometric results obtained are estimates linked to Fisher statistics on a hypothesis test that is related to assumptions on the coefficients of the variables studied (Bourbonnais, 2015).

In this context, as explained earlier, the more indebted a company is $\left(\boldsymbol{x}_{\mathbf{1}}\right)$, the higher its $\beta\left(\boldsymbol{y}_{\mathbf{1}}\right)$ would be $\left(\boldsymbol{H}_{1}\right)$. At the same time the higher the earnings growth rate $\left(\boldsymbol{x}_{\mathbf{2}}\right)$ the higher the $\beta\left(\boldsymbol{y}_{\mathbf{1}}\right)$ would be $\left(\boldsymbol{H}_{\mathbf{2}}\right)$.

The sub-panel gathered from the main sample, will be useful for a first confrontation between $\boldsymbol{y}_{1}$ and $\boldsymbol{x}_{1}$ on the one hand, and then between $\boldsymbol{y}_{1}$ and $\boldsymbol{x}_{2}$ on the other hand, in order to specify the panel behavior and its homogeneity.

The values of the Fisher statistic $\boldsymbol{F}_{\mathbf{1}}, \boldsymbol{F}_{\mathbf{2}}$ and $\boldsymbol{F}_{\mathbf{3}}$ related to the study of the hypotheses $\boldsymbol{H}_{\mathbf{1}}$ and $\boldsymbol{H}_{\mathbf{2}}$ are gathered in the following tables: 
TABLE 4

ESTIMATED VALUES OF F_1, F_2 AND F_3 AND THEIR P-VALUES

\begin{tabular}{|c|c|c|c|c|c|c|c|c|c|c|c|c|c|c|}
\hline \multirow{3}{*}{ 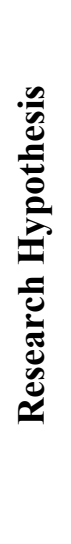 } & \multicolumn{2}{|c|}{$\begin{array}{c}\text { Study } \\
\text { variable }\end{array}$} & \multirow{3}{*}{ 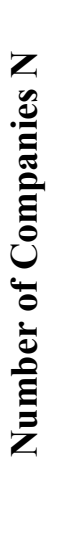 } & \multirow{3}{*}{ 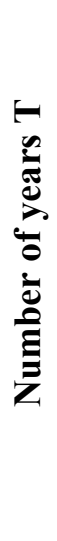 } & \multirow{3}{*}{ 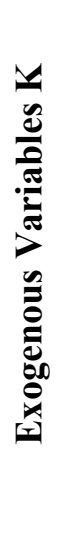 } & \multicolumn{9}{|c|}{ Fisher F } \\
\hline & \multirow[b]{2}{*}{ 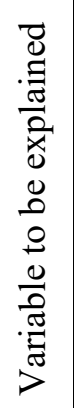 } & \multirow[b]{2}{*}{ 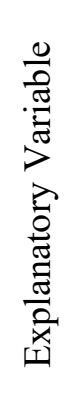 } & & & & \multicolumn{3}{|c|}{ F1 } & \multicolumn{3}{|c|}{ F2 } & \multicolumn{3}{|c|}{ F3 } \\
\hline & & & & & & 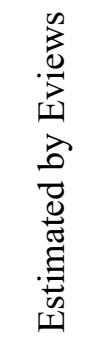 & $\frac{\frac{\vec{D}}{\frac{0}{\pi}}}{\frac{0}{\frac{0}{\pi}}}$ & $\begin{array}{l}\frac{0}{\pi} \\
\stackrel{\pi}{2} \\
2\end{array}$ & 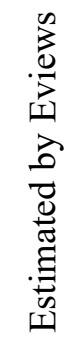 & 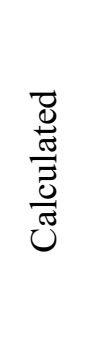 & $\frac{\mathscr{O}}{\stackrel{J}{J}}$ & 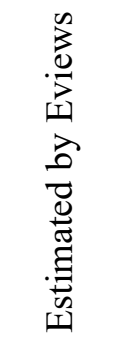 & 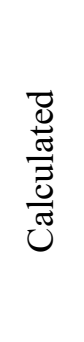 & $\begin{array}{l}\frac{0}{3} \\
\frac{\pi}{\pi} \\
2\end{array}$ \\
\hline H1 & Y1 & X1 & 44 & 8 & 1 & $\begin{array}{c}64.4 \\
2830\end{array}$ & $\begin{array}{c}1.32 \\
01\end{array}$ & $\begin{array}{c}4.0 \\
0 \mathrm{E}-138\end{array}$ & $\begin{array}{l}2.43 \\
203\end{array}$ & $\begin{array}{c}1.42 \\
64\end{array}$ & $\begin{array}{c}9.4 \\
7 \mathrm{E}- \\
06\end{array}$ & $\begin{array}{c}105.30 \\
307\end{array}$ & $\begin{array}{c}1.41 \\
99\end{array}$ & $\begin{array}{c}100 \mathrm{E}- \\
158\end{array}$ \\
\hline H2 & Y1 & $\mathrm{X} 2$ & 44 & 8 & 1 & $\begin{array}{c}51.79 \\
273\end{array}$ & $\begin{array}{c}1.32 \\
01\end{array}$ & $\begin{array}{c}1.9 \\
0 \mathrm{E}-126\end{array}$ & $\begin{array}{l}0.85 \\
240\end{array}$ & $\begin{array}{c}1.42 \\
64\end{array}$ & $\begin{array}{l}0.7 \\
31\end{array}$ & $\begin{array}{c}104.90 \\
172\end{array}$ & $\begin{array}{c}1.41 \\
99\end{array}$ & $\begin{array}{c}1.80 \mathrm{E}- \\
158\end{array}$ \\
\hline
\end{tabular}

Source: Compiled by authors.

TABLE 5

DETERMINATION OF THE NATURE OF THE STUDIED SUB-PANELS BY CONFRONTED VARIABLE

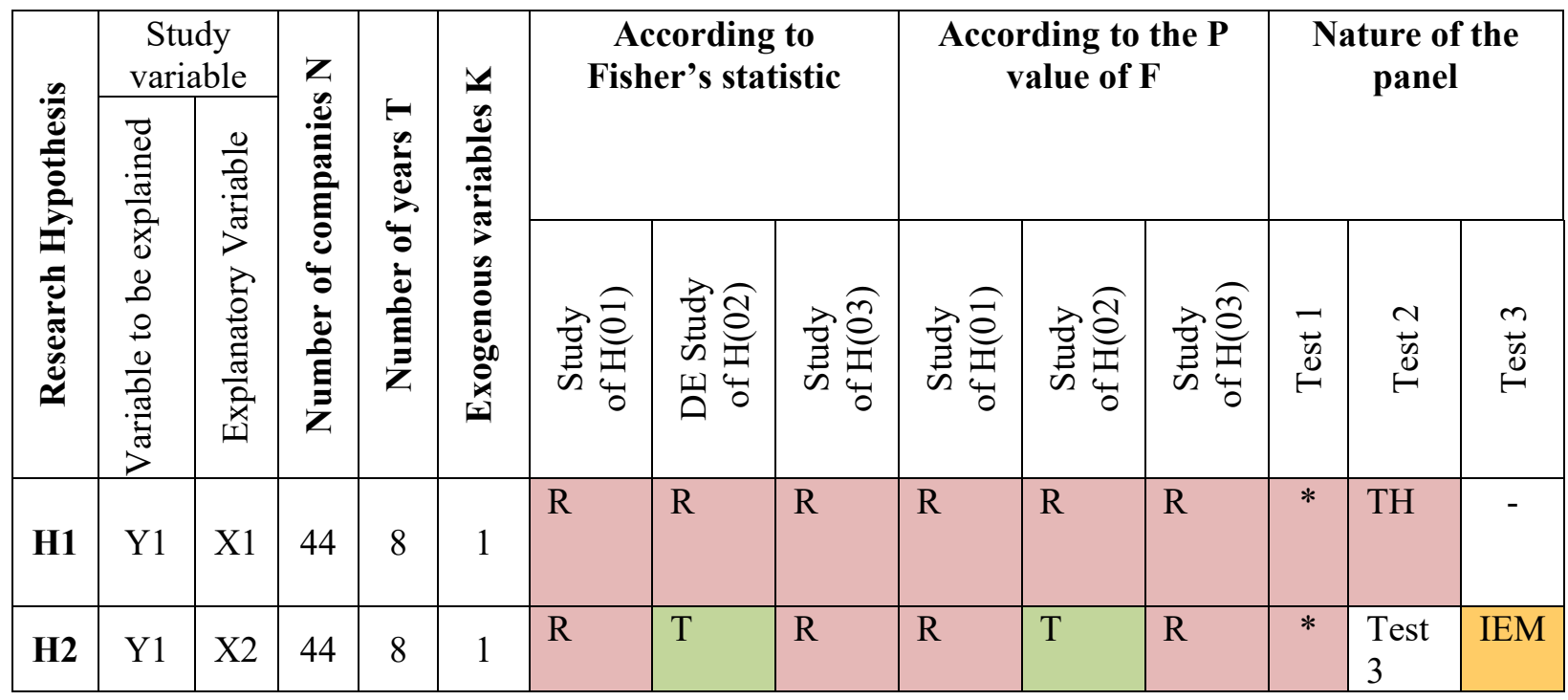

Source: Compiled by authors.

with:

R : Rejected;

T : True;

IEM: Individual effect model;

TH : Total heterogeneity. 
For the first hypothesis, the comparison between $\boldsymbol{y}_{\mathbf{1}}$ and $\boldsymbol{x}_{\mathbf{1}}$ showed that the panel $\left(\boldsymbol{y}_{\mathbf{1}} \boldsymbol{x}_{\mathbf{1}}\right)$, shows a total heterogeneity for which there is no possible link in time between $\boldsymbol{y}_{\mathbf{1}}$ and $\boldsymbol{x}_{\mathbf{1}}$. For the panel $\left(\boldsymbol{y}_{\mathbf{1}} \boldsymbol{x}_{\mathbf{2}}\right)$, according to the results of the estimations, it is said to have an individual effect $\left(\boldsymbol{y}_{2 ; \boldsymbol{i t}}=\boldsymbol{a}_{\boldsymbol{i t}}+\boldsymbol{a}^{\prime} \boldsymbol{x}_{\mathbf{2} ; \boldsymbol{i t}}+\boldsymbol{\varepsilon}_{\boldsymbol{i t}}\right)$ , for which we note that the constant values $\boldsymbol{a}_{\boldsymbol{o} i}$ differ among individuals, while the coefficients $\boldsymbol{a}_{\boldsymbol{i}}^{\prime}\left(\boldsymbol{a}_{\boldsymbol{i}}^{\prime}=\right.$ $\boldsymbol{a}^{\prime}$ ) of the explanatory variables are constant. Consequently, we note the absence of a perfect link over time between the variable to be explained $\boldsymbol{y}_{1}$, and the explanatory variables $\boldsymbol{x}_{\mathbf{1}}$ and $\boldsymbol{x}_{2}$.

This study's problem statement has led us to explain it through two hypotheses $\boldsymbol{H}_{\mathbf{1}}$ and $\boldsymbol{H}_{\mathbf{2}}$. For this reason, we used the gearing $\left(\boldsymbol{x}_{\mathbf{1}}\right)$ as an explanatory variable of the company's financial structure, and hence the financial risk related to the debt, as well as the growth rate of the earnings $\left(\boldsymbol{x}_{2}\right)$ as an element that also influences the company's $\beta$ eta.

Going back to $\boldsymbol{H}_{\mathbf{1}}$, we cannot confirm that debt directly impacts the $\beta$ eta of the company's stock. Following the panel results $\left(\boldsymbol{y}_{\mathbf{1}} \boldsymbol{x}_{2}\right)$, we can say that the relationship between the ßeta and the earnings growth is company specific. The generalization of this relationship remains invalidated.

From this, we note that hypotheses $\boldsymbol{H}_{\mathbf{1}}$ and $\boldsymbol{H}_{2}$ remain invalidated, in the absence of a direct confirmation, the company's financial risk is not directly impacted by the level of debt to equity or the volatility of the earnings growth rate.

\section{CONCLUSION}

As a result of these findings, the financial risk measured by ßeta among the companies in our study did not reflect any sensitivity to the choice of the financial structure and earnings growth rate. In corporate finance, the Beta is normally a function of these two components, as mentioned earlier. The case concerning us, was far from directly endorsing this direction of linkage, it remains unconfirmed for the panel ( $\boldsymbol{y}_{\mathbf{1}} \boldsymbol{x}_{\mathbf{2}}$; ßeta - earnings growth rate).

Regarding our first hypothesis, where it was assumed that the debt financing decision impacts the company's financial risk, we received results that broadly invalidated this hypothesis. In a very broad sense, $\beta$ eta measures the financial risk of a firm. By detailing it to the various types of financial risks which can affect the volatility of a share price, we can say in this regard, that the absence of a confirmed relationship between the $\beta$ eta and the gearing of a company on the one hand, and then the Beta and the volatility of the earnings or their variations on the other hand, can only be explained by the share of the debt risk compared to the other risks, which preponderantly influence the volatility of the share price of the companies in our sample. This share is surely insignificant to stand out from risks other than those of debt.

After the invalidation of the hypotheses of this study, it is clear that debt financing decisions do not have a primary influence on the $\beta$ eta of the companies studied. Following the second comparison between the $\beta$ eta and the earnings growth rate, where the contribution was negative, the income flows determine, over time, the value of the company following a valuation approach by the flows, something which has not been confirmed. Thus, we return in this case, to a neutrality of the financial structure on the Beta displayed by these companies.

\section{ACKNOWLEDGEMENT}

Translated \& edited by American Publishing Services (https://americanpublishingservices.com/).

\section{ENDNOTES}

1. It is assumed in this case that the specific risk is purely a financial risk for companies of the same activity.

2. $\frac{D}{C P+D}=\frac{1}{\frac{C P}{D}+1}=\frac{1}{\frac{1}{\text { gearing }}+1}$ 


\section{REFERENCES}

Aivazian, V.A., Ge, Y., \& Qiu, J. (2005). Debt maturity structure and firm investment. Financial Management, 34(4), 107-119.

Bancel, F., Lathuille, Q., \& Lhuissier, A. (2014). De la difficulté de mesurer le coût du capital. Revue Française de Gestion, 242(2014), 103-118.

Beattie, V., \& Goodacre, S.J.T. (2006). Corporate financing decisions: UK Survey Evidence. Journal of Business Finance \& Accounting, 33(9/10), 1402-1434.

Bourbonnais, R. (2015). Économétrie: Cours et exercices corrigés (9ème edition). Paris. Dunod.

Ding, N., Bhat, K., \& Jebran, K. (2020). Debt choice, growth opportunities and corporate investment: Evidence from China. Financial Innovation, 31(6), 1-22.

Fama, E.F., \& French, K.R. (2005). Financing Decisions: Who Issues Stock ? Journal of Financial Economics, 76(3), 549-582

Leland, H. (1994). Corporate Debt Value, Bond Covenants and Optimal Capital Structure. Journal of Finance, 49(4), 1213-1252.

Modigliani, H.M. (1958). The Cost of Capital, Corporation Finance and the Theory of Investment. American Economic Review, 48(3), 261-297.

Molay, E. (2010). Un test de la théorie du financement hiérarchisé sur données de panel françaises. Hal: PostPrint, pp. 1-24.

Ross, S.A. (1977). The Determination of Financial Structure: The Incentive-Signalling Approach. Bell Journal of Economics, 8(1), 23-40.

Sharpe, W.F. (1964). Capital asset prices: A theory of market equilibrium under conditions of risk. Journal of Finance, 19(3), 425-442.

Vernimmen Lettre $\mathrm{N}^{\circ} 23$. (2003, October/November). Actualités : Bêta des capitaux propres, Bêta de l'endettement et Bêta de l'actif économique. 


\section{APPENDIX 1}

The Distribution of the Companies in the Sample by Sectoral Capitalisation

\begin{tabular}{|c|c|c|c|c|}
\hline Business Sector & Facility & $\begin{array}{c}\text { Market } \\
\text { capitalization }\end{array}$ & $\begin{array}{c}\text { Sectorial } \\
\text { Capitalization }\end{array}$ & Share in $\%$ \\
\hline \multirow{6}{*}{ Agri-food Processing } & CARTIER SAADA & 168480000 & \multirow{6}{*}{34902774993} & \multirow{6}{*}{$10,79 \%$} \\
\hline & CENTRALE DANONE & 5925180000 & & \\
\hline & COSUMAR & 20683235603 & & \\
\hline & DARI COUSPATE & 1234675750 & & \\
\hline & LESIEUR CRISTAL & 4973671800 & & \\
\hline & UNIMER & 1917531840 & & \\
\hline \multirow{5}{*}{ Building and Construction Materials } & ALUMINIUM DU MAROC & 783268674 & \multirow{5}{*}{69745560141} & \multirow{5}{*}{$21,56 \%$} \\
\hline & CIMENTS DU MAROC & 23963766640 & & \\
\hline & COLORADO & 675730827 & & \\
\hline & LAFARGEHOLCIM MAR & 43347794000 & & \\
\hline & SONASID & 975000000 & & \\
\hline \multirow{2}{*}{ Beverage } & SOCIETE DES BOISSONS DU MAROC & 8064511050 & \multirow{2}{*}{10996891050} & \multirow{2}{*}{$3,40 \%$} \\
\hline & OULMES & 2932380000 & & \\
\hline \multirow{2}{*}{ Chemicals } & MAGHREB OXYGENE & 156731250 & \multirow{2}{*}{1301531250} & \multirow{2}{*}{$0,40 \%$} \\
\hline & SNEP & 1144800000 & & \\
\hline \multirow{6}{*}{ Distributors } & AUTO HALL & 4023562240 & \multirow{6}{*}{14162031643} & \multirow{6}{*}{$4,37 \%$} \\
\hline & AUTO NEJMA & 2251180800 & & \\
\hline & FENNIE BROSSETTE & 111593209 & & \\
\hline & LABEL VIE & 7616935046 & & \\
\hline & REALISATIONS MECANIQUE & 60832000 & & \\
\hline & STOKVIS NORD AFRIQUE & 97928348 & & \\
\hline Electronic and electrical equipment & NEXANS MAROC & 301977792 & 301977792 & $0,09 \%$ \\
\hline \multirow[t]{2}{*}{ Pharmaceutical Industry } & PROMOPHARM S.A & 856000000 & \multirow[t]{2}{*}{3773800000} & \multirow[t]{2}{*}{$1,16 \%$} \\
\hline & SOTHEMA & 2917800000 & & \\
\hline Engine ering and industrial equipment & DELATTRE LEVIVIER MAROC & 65000000 & 65000000 & $0,02 \%$ \\
\hline Leisure and Hotels & RISMA & 2435580990 & 2435580990 & $0,75 \%$ \\
\hline \multirow{5}{*}{ Hardware, software, and computer services } & HPS & 2638496250 & \multirow{5}{*}{3895016567} & \multirow{5}{*}{$1,20 \%$} \\
\hline & IB MAROC.COM & 18315111 & & \\
\hline & INVOLYS & 61234560 & & \\
\hline & M2M GROUP & 387370646 & & \\
\hline & MICRODATA & 789600000 & & \\
\hline
\end{tabular}




\begin{tabular}{|c|c|c|c|c|}
\hline $\begin{array}{l}\text { Business } \\
\text { Sector }\end{array}$ & Facility & Market capitalization & Sectorial Capitalization & Share in \% \\
\hline \multirow{2}{*}{ Mining } & MANAGEM & 8492611800 & \multirow{2}{*}{11072112920} & \multirow{2}{*}{$3,42 \%$} \\
\hline & SMI & 2579501120 & & \\
\hline \multirow{2}{*}{$\begin{array}{l}\text { Real estate } \\
\text { investmant } \\
\text { and promotion }\end{array}$} & ALLIANCES & 1236400928 & \multirow[t]{2}{*}{4894198646} & \multirow[t]{2}{*}{$1,51 \%$} \\
\hline & DOUJA PROM ADDOHA & 3657797718 & & \\
\hline \multirow{2}{*}{ Oil \& Gas } & AFRIQUIA GAZ & 13065937500 & \multirow{2}{*}{23522257500} & \multirow{2}{*}{$7,27 \%$} \\
\hline & TOTAL MAROC & 10456320000 & & \\
\hline \begin{tabular}{|l|}
$\begin{array}{l}\text { Coporate } \\
\text { services }\end{array}$ \\
\end{tabular} & LYDEC & 3567200000 & 3567200000 & $1,10 \%$ \\
\hline $\begin{array}{l}\text { Real estate } \\
\text { investmant } \\
\text { trusts }\end{array}$ & BALIMA & 150681600 & 150681600 & $0,04 \%$ \\
\hline $\begin{array}{l}\text { Holding } \\
\text { companies }\end{array}$ & DELTA HOLDING & 2995920000 & 2995920000 & $0,92 \%$ \\
\hline $\begin{array}{l}\text { Forestry and } \\
\text { Paper }\end{array}$ & MED PAPER & 51651100 & 51651100 & $0,01 \%$ \\
\hline $\begin{array}{l}\text { Telecommunic } \\
\text { ations }\end{array}$ & ITISSALAT AL-MAGHREB & 134501587020 & 134501587020 & $41,58 \%$ \\
\hline \multirow{2}{*}{ Transport } & CTM & 1054341080 & \multirow{2}{*}{1104624780} & \multirow{2}{*}{$0,34 \%$} \\
\hline & TIMAR & 50283700 & & \\
\hline TOTALS & 44 & 323440397992 & 323440397992 & $100 \%$ \\
\hline
\end{tabular}




\section{APPENDIX 2}

Specification of the Panel (Y1 X1): The Beta \# The Gearing

Dependent Variable: Y1?

Method: Pooled Least Squares

Sample: 20122019

Included observations: 8

Cross-sections included: 44

Total pool (balanced) observations: 352

\begin{tabular}{|c|c|c|c|c|}
\hline Variable & Coefficient & Std. Error & t-Statistic & Prob. \\
\hline C & 0.560042 & 0.010274 & 54.50884 & 0.0000 \\
\hline $\mathrm{X} 1 ?$ & -0.000611 & 0.000548 & -1.114491 & 0.2659 \\
\hline \multicolumn{5}{|c|}{ Fixed Effects (Cross) } \\
\hline -1--C & 0.594281 & & _23--C & 0.254506 \\
\hline -2--C & 0.400566 & & 24--C & -0.097656 \\
\hline -3--C & -0.141845 & & _25--C & 1.384175 \\
\hline$-4--C$ & 0.061372 & & - $26--\mathrm{C}$ & 0.105924 \\
\hline $5--C$ & 0.385011 & & $27--\mathrm{C}$ & 0.372265 \\
\hline -6--C & -0.342361 & & $28--C$ & -0.347024 \\
\hline -7--C & -0.562761 & & _29--C & -0.281843 \\
\hline -8--C & -0.187285 & & $30--C$ & 0.615188 \\
\hline -9--C & -0.270575 & & $31--C$ & -0.037783 \\
\hline -10--C & -0.325068 & & 32--C & -0.037649 \\
\hline $11--C$ & 0.763259 & & 33--C & -0.530245 \\
\hline $12--C$ & -0.082901 & & $34--\mathrm{C}$ & -0.256903 \\
\hline$-13--C$ & 0.277587 & & -35--C & -0.445707 \\
\hline _14--C & 0.188225 & & _36--C & 0.033975 \\
\hline $15--C$ & -0.402759 & & $37--C$ & 0.337559 \\
\hline -16--C & -0.226545 & & $38--C$ & -0.278225 \\
\hline $17--C$ & -0.235859 & & 39--C & -0.223031 \\
\hline $18--C$ & 0.591715 & & $-40--C$ & \multirow{2}{*}{$\begin{array}{c}0.542172 \\
-0375826\end{array}$} \\
\hline 19--C & -0.042532 & & $41--\mathrm{C}$ & \\
\hline 20--C & 0.168665 & & $42--C$ & -0.149653 \\
\hline -21--C & -0.070404 & & _43--C & -0.460566 \\
\hline -22--C & -0.133513 & & $-{ }^{44--C}$ & -0.529923 \\
\hline \multicolumn{5}{|c|}{ Effects Specificatic } \\
\hline \multicolumn{5}{|c|}{ Cross-section fixed (dummy variables) } \\
\hline R-squared & 0.8 & \multirow{2}{*}{\multicolumn{2}{|c|}{$\begin{array}{l}\text { Mean dependent var } \\
\text { S.D. dependent var }\end{array}$}} & 0.559150 \\
\hline Adjusted R-sc & 0.811460 & & & 0.442589 \\
\hline S.E. of regression & 0.192178 & \multicolumn{2}{|c|}{ Akaike info criterion } & -0.341894 \\
\hline Sum squared resid & 11.33821 & Schwarz cr & terion & 0.152036 \\
\hline Log likelihood & 105.1734 & Hannan-Qu & inn criter. & -0.145334 \\
\hline F-statistic & 35.33342 & Durbin-Wat & son stat & 0.628697 \\
\hline Prob(F-statistic) & 0.000000 & & & \\
\hline
\end{tabular}




\section{APPENDIX 3}

\section{Specification of the Panel (Y1 X2): The Beta \# The Earnings Growth Rate}

Dependent Variable: Y1?

Method: Pooled Least Squares

Sample: 20122019

Included observations: 8

Cross-sections included: 44

Total pool (balanced) observations: 352

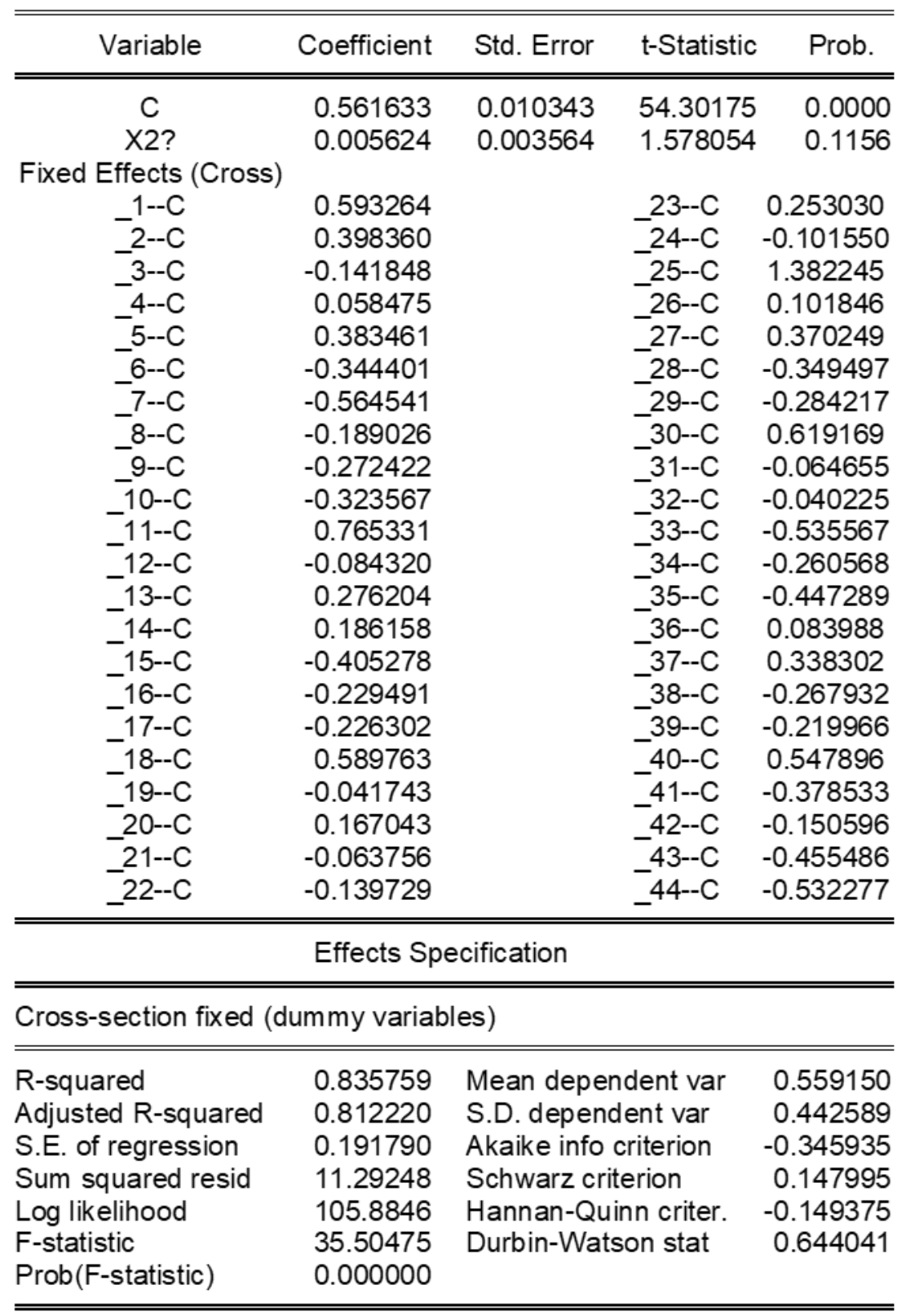

74 Journal of Accounting and Finance Vol. 21(5) 2021 